\title{
The Power of Emotional Factors in English Teaching
}

\author{
DAVID R. COLE \\ University of Technology, Sydney, Australia
}

\begin{abstract}
One of the most prevalent ways in which power works in education is by separating out and segmenting knowledge areas so that their corresponding synergies and connective augmentations are nullified. This article takes secondary English teaching as an example of these complex social processes, and presents research that brings disparate fields of investigation together. On the one hand, teachers may be polarised and challenged by curriculum changes and governmental mandates that could infringe upon their everyday practice. On the other, every teacher in the profession will bring their interior and emotional life to bear on their ways of working, and this aspect of teaching has not been connected to curriculum change. This research proposes a conjunction of educational emotion and discursive identities, through an analysis of the ways in which teachers perceive curriculum change and their personal teaching and learning realities. This investigation has also been worked into the teacher training of pre-service (or trainee) secondary English teachers, so that they may realise how such concerns may be understood conjointly.
\end{abstract}

\section{Introduction}

Teaching English in secondary schools brings together internal and external influences. The most pressing external influence is often the particular curriculum design that is being used in the zone that places and contextualises English within a knowledge system. Animating this design are social forces such as the importance of English to the community and the ways in which English may explore identity through literature (Doecke et al, 2006). Internal influence on the English teaching that happens in the classroom is more complex, as particular teachers will bring their own motivations and conceptual understandings about English to bear on their teaching (Kress, 2006).

This article puts the field of knowledge about English teaching into play through the curriculum changes that have recently been happening on the island of Tasmania, Australia due to the introduction of a framework called Essential Learnings (see Appendix 1) and explanations about the emotional parts of teaching English from secondary practitioners. It aims to join the internal and external dimensions of English teachers' professional lives to the benefit of the student trainee teachers undertaking the research, the readers of this article and the main researcher who has brought this evidence and thinking together. This joining exemplifies the value of research as a nexus for understanding complex aspects of English teaching (Cole, 2007a) and exploring the ways in which this complexity may be represented to challenge power concerns that might separate emotion from identity and change.

\section{Methodology}

The Bachelor of Teaching course that pre-service trainee English teachers follow in Tasmania is a postgraduate qualification - and includes aspects of educational research training. This project that 
has been designed for them as part of this training and is a form of action research (Martin et al, 2006). The student teachers learn through doing - in this case talking to in-service English teachers and gauging their opinions and ideas with respect to curriculum change and emotion. Fifty-eight secondary English teachers were interviewed for this project in their place of work for up to an hour and a half at a time. These teachers constitute a random sample of different ages, ethnicities and gender. The student teachers were required to write up their research in the manner of a minithesis, building literature reviews, coding, analysis and critical evaluation of the themes that emerged from the semi-structured interviews and any observations that they undertook in the schools. In this way, the quality of their research was monitored and evaluated by the main researcher, who marked and discussed the results with the students. This project gained full local ethics clearance, both in terms of the students using the data for their own projects, and the aggregation of the evidence that is represented by this article. Students supplemented their data with self-reflective diaries and notes from teaching on four practicum experiences over two years.

The teachers who were interviewed read an information sheet about the research and signed a consent form to take part. The students designed an appropriate research instrument, which included open-ended and informational questions about emotion and curriculum change (Gubrium $\&$ Holstein, 2002). Specific questions that ran through the research designs included: 'What is the reaction of the teachers to curriculum change in Tasmania?' and 'Discuss the emotional factors that permeate your English teaching'. The students' analysis of the data depended on their ability to make qualitative distinctions in the transcripts (Upton, 2005), and to isolate themes in the research that corresponded to curriculum change and emotional proclivity. This article has been organised by the lecturer and main researcher running the course with the consent of the students and teachers, and provides an overview of the results obtained by them over four years.

The sections that follow differentiate between different English teacher types. This set of categories relates to curriculum change and the effects of the Essential Learnings (Appendix 1). These teacher types are not sketchy characterisations of typical English teachers (Marshall, 2000) or crude stereotypes, but constitute a discourse analysis (Fairclough, 1992) of the complex identity resources available to English teachers in Tasmania during the research and time of change. The resultant Discourses are wholly interrelated and may coexist in the same subject, yet for the purposes of representation have been separated by the main researcher from the evidence as it was presented by the students and after intense discussion. The data that is included in the Discourses serves as evidence, and is also related on many levels to the power and identity structures that are present (Cole, 2005) in the English teaching system of Tasmania. The distinction used here between Discourses and discourses works in this article to pinpoint those governmental forms of communication - Discourses - that carry power concerns and identity constructions, and everyday forms of language use - discourses (Gee, 2003). The overall research question for this section is: What are the categories of English teacher identity that one might discern after the introduction of the Essential Learnings?

\section{The Essential Learnings (ELs)}

The Essential Learnings was implemented in the Australian state of Tasmania in 2002 after many years of public consultation and debate (Watt, 2005) and is parallel to other Australian curricula such as the Victorian Essential Learnings (VELs). It is a knowledge framework based on constructivist and integrated curriculum principles (Dowden \& Nolan, 2006). According to the ELs, the teaching of English is henceforth integrated into the Essential Learning of Communicating.

As one might discern, the teaching of English is reorganised through this model - Being literate is valued alongside numeracy, information and arts literacy. Teachers should design units of work according to generative themes, and include communicative opportunities under these themes through which the students will improve their literacy skills. The ELs is assessed through standards that relate to each element in the framework; for secondary English teachers, the standards of Being literate are of primary concern. For many years, English was taught in Tasmanian secondary schools in a traditional manner, without a fixed curriculum model. This teaching was constituted by the study of classic and contemporary English texts from years 7 to 10, and marked against a set of state-wide English standards. According to the guidelines of the ELs, English teachers should 
now shape their lessons to suit communicative outcomes, and this has resulted in three distinctive reactions that one can use to understand English teacher identities (Discourses) with respect to this curriculum change. These categories were arrived at through rigorous discussion and debate between the student researchers and the lecturer.

\section{Essential Learners}

These teachers are thoroughly convinced that the ELs is a step in the right direction. They agree with it because it restructures the teaching of English with respect to social and cultural factors. According to this perspective, English in the secondary context becomes more aligned and integrated with the primary area of literacy, which enables learners to communicate effectively using words whilst thinking critically about text. For example:

Teacher A: The ELs has given me the chance to really start planning some relevant lessons for the kids. I work in a school with a severely disadvantaged cohort. They have no money, and they come from families with no money. Now we don't have to go through the motions of studying a novel or planning gap-fillers to use up the time. We can do work that will help this group in the real world - to earn money!

It could be argued that the ELs provides continuity and scaffolding between primary and secondary language learning. Essential learners may well be sympathetic to whole language philosophy, and integrate critical literacy into their everyday English teaching through interdisciplinary units of work. The new knowledge framework (ELs) fits in with a socially constructed view of English teaching.

\section{Neutral Pragmatists}

The in-service English teachers in this group identify curriculum changes as exterior to their personal beliefs about English teaching. As such, they will take on board some of the tenets of the ELs without being overly concerned about implementation. Neutral pragmatists will go about their business of teaching English through text and organising the curriculum according to traditional definitions of English such as teaching the classics, yet they are able to fit in their lesson ideas with the ELs. For example:

\footnotetext{
Teacher B: I'm most familiar with Communicating, Being Literate and Being Arts Literate. I've sat down, and wrote my own rubrics - and that takes a lot of time, and it takes a lot of time to assess, 'cause you sit there with your school's understanding of it, and the actual ELs folder understanding of it, and whatever you've done with the rubric, and it takes probably five times as long to mark things. We are progressing, and getting there. I will work my way through this new system. It's hard to hand down to the kids as well, because they look at these numbers and they're not exactly sure what they mean.
}

The pragmatists will use aspects of critical literacy and child-centred learning - yet will not articulate a specific mandate to make any changes in the curriculum through their teaching and learning. These teachers perceive the new knowledge framework to be an outside influence, to be tolerated and worked with, but without transformative power, which is located in their classroom practice and the agreements that they come to with their students.

\section{Defenders of the Canon}

The third reaction to the introduction of the ELs that this research has uncovered is that it is a threat to subject integrity. These English teachers not only consider this reform to be a matter of interference in their teaching practices, they also believe it to be wrong. This is because the ELs impinges on their beliefs about the canon of English literature, and the appropriate pedagogies to get this body of work across. This teachers in this group are vocal opponents of the ELs, perhaps supporting other, more traditional curricula, where the subject disciplines are rigidly differentiated into subject areas. For example: 
Teacher C: I'm worried about social engineering, and I'm worried about that in ELs and critical literacy ... in the ELs, for example, there are these world futures and personal futures. Now, somewhere, someone's decided, if you're going to assess someone on world futures, someone's obviously got an idea about what they would like the world to be like ... but if I buy that teachers are able to sell a worldview - what happens when it's not one I like?

These teachers may hold a cultural heritage or skills-based approach to teaching English that is shaped by direct instruction and the pivotal role of the English teacher to pass on truths about English cultural life.

\section{Interdisciplinary Subject Area}

One of the most prevalent educational issues that this research has identified is the contrast between interdisciplinary knowledge, and the preservation of the subject disciplines in the secondary context (Shulman, 1986). The ELs lends itself to working across subject areas, and developing integrated units of work around generative topics. The intense discussion and analysis of the transcripts has shown that English teachers fall into two Discourse categories with respect to interdisciplinary work.

\section{Vocational Project Managers}

These teachers fully embrace interdisciplinary working. The reorganisation of English into communication studies suits them as they enjoy the real-life contexts and the freedom to explore the media. Such teachers take pedagogies from the perspective of multiliteracies (Mills, 2005), so that students use research and critical analysis to examine social phenomena through reading and writing projects (Mills, 2006). For example:

Teacher D: We were doing a unit of work on autobiography. The issue of motorbikes came up! We decided to follow this theme, and did research into the sales and branding of motorbikes. We looked at the gender stereotypes around motorbikes. Students found out about biker gangs, we looked at where they lived, what they believed in and what types of people they were. We did market research and critical analysis of the image of bikers and the associated gender stereotypes.

It could be argued that opening English up to the interdisciplinary style of planning and teaching is a response to new cultural conditions. Students will have to become literate in different ways in the twenty-first century, and their repertoires of literate activities should be aligned with these changes (Cole, 2007b). Interdisciplinary work gives English teachers the freedom to explore this terrain, and to teach students relevant skills for today's workforce. Vocational project managers believe that English should be aligned to new workplace arrangements and the communication skills necessary to succeed in these environments.

\section{Tireless Bookworms}

These English teachers will accept the fact that the world is changing - but simultaneously believe that the basis for secondary English teaching and learning is print literacy. Students should therefore have the opportunity to study written text in a direct manner, learning about written effects such as metaphor, verisimilitude and hyperbole. Bookworms will search out reading opportunities for their students and design pedagogies that enhance the reading experience. For example:

Teacher E: Last year I read a book called Hana's Suitcase by Karen Devine. I found it so moving that I wanted to share it with my class. Even though I only had one copy, I was determined to use this book and we worked our way through it together and it has turned into one of the best teaching experiences that I have ever had. I believe that the class felt that I had been moved by this book, and they were too.

Bookworms will organise writing exercises that test the skills of their students to work in different genres (Derewianka, 1998). They will look at interdisciplinary work with suspicion, as it may 
constitute a threat to their understanding of reading and writing print text as primary. Bookworms will use many discursive and oral strategies in their English teaching, but these lesson segments and connectives will not usually be too far removed from a printed text source such as a script or a speech.

\section{Critical Literacy}

The issues with regard to the status and use of critical literacy in English get to the heart of the changes that these Discourses explore. The ELs has put critical literacy at the centre of Being literate and therefore prioritises its potential. This is perhaps an ironic counterpoint to traditional notions of textual authority and the mandates that emerge from governmental and bureaucratic offices. It could be suggested that most system control centres would not encourage critical exploration of controversies and the questioning of their texts. After close and animated scrutiny, it was found that teachers reacted according to two opposing Discourses to questions about critical literacy.

\section{Textual Revolutionaries}

This research found that there are English teachers who are wholly in agreement with the critical literacy approach to English teaching. Not only does it fit in with their beliefs about making a difference in the classroom, it also gives their lessons a purpose and meaning beyond confined interaction with the students. Such teachers will seek out text that can be used for the purposes of social justice and egalitarianism. They will not shy away from exploring the media, and addressing issues such as racism, misogyny and the environment. Textual revolutionaries will include poststructural thinking in their approaches to text (Mellor \& Patterson, 2004).

Teacher F: The problem with English teaching has been for many years that it has not addressed fundamental social problems. Therefore there was no point to it other than improving the student's level of English and perhaps some polite edification through reading. Now we have a framework to make a difference - I really appreciate that.

The textual revolutionaries will highlight the ways in which those in power have constructed meaning, and they will look for different positions in English teaching to make sense through text such as post-colonialist, feminist or environmentalist perspectives. These English teachers will be politically motivated in terms of making a difference in society - and they will use this objective as an animating force in English classrooms. They believe wholeheartedly that it is a teacher's job to educate their students to be able to articulate their own opinions, especially if this means going against the norm (Cole, 2007c) or standing up for fundamental rights.

\section{English 'Royales'}

Counter-arguments against critical literacy were not found to be as prevalent in the English teachers questioned for this research. Perhaps this was because the teachers in Tasmania were acting through the Discourse of pragmatic neutrality, as they thought it might be imprudent to speak out openly against critical literacy. Those who did, however, spoke about the suffocating and conformist English teaching agenda that critical literacy can produce. They indicated that changing the world through English teaching is unrealistic and idealistic. These English teachers believe that students need sets of values that may be delivered through quality literature. For example:

Teacher C: You should remember that English isn't just about language and literacy skills - it is about ideas. In the absence of philosophy being well taught in schools, English can be a quasiphilosophy at times - it's about coming to terms with issues in life and the textual responses to these issues. It is not about giving students one certain answer or point of view.

The English 'royales' are sceptical with respect to politically motivated teaching and suspicious of leading the students to a pre-conceived position on a text. They are aligned with the defenders of the canon, and select their texts from English literature to give their students a flavour of writing throughout history. 


\section{Emotions and Teaching English}

The second part of the research presented the greatest challenge for the pre-service students. The aim was to examine the emotional side of English teaching. Once the teachers' ideas with respect to the ELs had been ascertained, the researchers were to pursue the emotions involved with teaching English. Clearly, this could lead the interview in a number of different directions (Strauss $\&$ Corbin, 1998). The pre-service students used open-ended questions to allow the teachers to tell their stories, and to explore how emotion permeates their practice. The teachers were encouraged to speak about their personal emotions, student emotions, emotions in the books that they were studying, or emotions that might be stirred up in the classroom due to the examination of textrelated issues. The second part of the research depended upon the quality of the relationship that the student-researcher had managed to strike up with the teacher, and was not designed to be psychoanalytic. It should be noted that the representation of emotional phenomena in English teaching has come about in the context of a trainee teacher interviewing a fully trained teacher. This creates a certain angle to the data, in that the teachers may well have added pedagogic value to their 'emotionality' as they spoke to the trainees.

The analyses that follow about emotions and English cannot be differentiated as Discourses of interrelated teacher types. This is because the emotional factors that are being represented here are by nature complex in that they are not unambiguous labels or clear categories that separate opinion (Chevellard, 1991). The following headings were arrived at after rigorous discussion between the pre-service students and the main researcher. In a parallel manner to the Discourse types, they are highly interrelated, and represent a qualitatively themed analysis of the data on emotions and secondary English teaching in Tasmania during 2004-2007. The primary research question here is: What are the ways in which emotion works in your English class?

\section{Maturation}

The research has shown that teachers construct English teaching differently as they mature into the job. At the beginning of their careers, many of them were trained to use emotions in the text to create lively and interactive learning environments. Perhaps they were responding to reader response or the personal growth theory of English teaching (Sawyer, 2004). Whatever the precise reason for the initial integration of emotional textual stimulation into their practice, they tend to personally value these tactics less as they have matured. For example:

Teacher G: My ideas have changed over the years - when I was an early teacher, I did a lot of teaching that I hoped was affecting students in an emotional and empathetic way - now I'm moving away from that model. I'm still looking at literature in the way it has an effect on students, but I don't want my students to be affected by the characters and the work in the same way. I actually want them to be more involved with the writer, the intended audience, the gaps and silences in the text, the purposes within the text.

Teachers at the beginning of their careers found it more difficult to speak about ways of working with text to enhance emotion, both in terms of their own emotions and emotions that come about due to reading texts. For example:

Teacher L: I have just started teaching and I have had a terrible time getting the kids to talk about anything! I remember having great discussions at school about characters in books and important issues. My students just don't want to say anything.

Perhaps because the emotions of beginning teachers are sometimes under pressure in the classroom context, textual emotions are more difficult to locate, address and articulate (Holland, 1968). The interview transcripts point towards a complex relationship between the use of emotions in English as a textual practice, the understanding of how to use emotions by particular English teachers and the articulation of emotion in their work. This relationship must also take into account the ways in which habit and conditioning may make emotions part of the automatic working in the classroom (Varela et al, 1993) - which also points to maturation as being pivotal in terms of English teaching and emotion. This is reinforced by the ways in which English teaching becomes easier as practitioners mature into the job. At the beginning of their careers, English 
teachers might find it hard to separate their own emotional involvement with a lesson from the emotions that might be stirred up from reading a text (Doecke, 2006).

\section{Gender}

The interviews show that gender has a part to play with respect to emotion in English, both in terms of students reacting to texts and gendered emotional relationships in the English classroom. For example, boys sometimes found it difficult to take on role-plays, or to empathise with characters in the text. Girls, however, more frequently have no problem in identifying with characters, understanding the emotions with respect to the text, and completing work that requires them to analyse relationships in the text. Gender therefore plays a role in secondary English in that engagement with literature requires emotional processes that may become gendered: For example:

Teacher H: ... it can be a struggle with boys to get a deep response out of them. It just usually requires you to pull back or alter the task in some way so that they are not obviously traumatised by the experience.

Teacher I: Something I find interesting though is that girls, perhaps because they are conditioned, are more likely to identify with the obvious male characters and feel quite happy talking about that identification, the emotions and the situation than boys do with female characters.

Teachers commented that work around gender stereotypes and relationships between genders can have a positive impact in English classes, in that the emotional proclivities stirred up by gender in the classroom may be resolved and articulated through the third person of the text. Teachers willing and able to use textual emotion positively in the classroom will stimulate differences through these practices (Cole, 2007a); those perhaps preferring a quiet life will yearn for single-sex English classrooms! The results of this research do not point to binary gendered opposites in English teaching, but show how classroom experience may be intensified through understanding the roles of gender in English studies.

\section{Power}

The third heading for emotions and English that this research and the debriefings picked up was power. Many pre-service students have benefited from this as they may have come into teacher training with misconceptions about teacher power and the use of power in the classroom. They have found out that teachers feel empowered through an emotional connection with their job they could also feel disempowered if this emotional connection is broken. The power of the English teacher was prevalent when he or she worked with a group with definite objectives and processes. The disempowered teachers were still working through power differentials. For example:

Teacher $K$ : At the end of the year, the grade 11 class wrote a letter about the behavioural problems that we had been experiencing. They said that there had been a personality clash. I don't believe in personality clashes myself. The secret to survival in that class was one boy who took an age to come around. Once he was on board and working with me, the rest of the group complied. They realised that I was the one with the power, and that the student was engaging in a power-stunt.

This teacher shows how power problems in the classroom may resolve themselves through dialogue and emotional alignment. The disempowered teacher is unconnected to the will of the group, and feels a gulf between their expectations and the class reality. Clearly, this emotional aspect of English teaching has a lot to do with behaviour management. Teachers who perceive their job to be a daily battle with teenagers will feel disempowered; those who understand their working lives as a synchronised movement towards enhanced communal literacy are more likely to revel in their existence (McWilliam, 2000). 


\section{Affects in English Teaching}

The students and the main researcher discussed affects and their relationship with teaching English before doing the fieldwork. Affects were distinguished from emotions by understanding that emotions are connected to the personality of the teachers, whereas affects are connections between people and text and reading that may provoke emotions (Holland, 1968). It was agreed that affects were useful with respect to talking about how English classrooms work on a less personal level than emotions (Keen, 2006). It was hoped that discussing affects would elicit less reactive responses from the English teachers than directly asking them about emotions, whilst still producing useful information on current English practice and identity. Affects can only be differentiated via interrelated themes, which do not define Discourses or identity resources as the conversations that emerged around them are not structured as constituting persons. The headings below were arrived at after rigorous and open analysis of the interview transcripts between pre-service students and the main researcher. The research questions here are: What affects help to make your classes work? What affects might cause difficulties in your English teaching?

\section{Creativity}

Many teachers spoke to the students about how to be creative in the English classroom. This is a personal goal in terms of not endlessly repeating the same photocopied lessons, as well as being a social objective (Houtz \& Krug, 1995). Students need to be skilled in creativity in their language usage, as the communication abilities demanded of them in the contemporary workplace are increasingly disparate (Cope \& Kalantzis, 1995). Affects are related to these changes in English teaching and identities that the improved creativity demands, as teachers have to continually work on the level of relationships with their students. Affects are also expressions of desire (Semetsky, 2007) that may be differentiated from emotions in that they relate to the atmosphere that the English lessons produce. For example:

Teacher H: So sometimes very deep affective learning can come out of life writing and I have to try and say you are not writing just to be cathartic and for your own personal counselling here, there has to be an awareness of audience as well as learning outcomes and a valid learning experience going on. At this level teenagers sometimes don't know the difference and I feel I've got to be the one that arbitrates.

This teacher pinpoints how affects are connected to creativity, and the ways in which language use may alter when engaging with creative writing. In an increasingly diverse social environment and with the acceptance that this diversity should be used and celebrated (Graham, 2007) in teaching, English teachers should look at new ways to make their lessons appealing. The use of technology shows one possible route and the affects that are produced through multimedia are an important zone for English teachers to explore: for example, media studies, film, advertising and the Internet (Cole, 2005). Furthermore, the increasing prominence of family literacy, personal literacy and English as a second language as part of mainstream English practice (Cardiero-Kaplan, 2004) shows us how English teaching is evolving and affects are part of this evolution. The students found that some teachers were reluctant to talk about these changes in English, as it can involve new skills for them to learn. However, those who did accept changing demographics would engage in discussing the use of affects to get their classes to work creatively through building positive relationships. Examples that were given of using affect for creativity included: scenarios to build vocabulary, working with communicative competence and engagement, and exploring the cultural perceptions and desires that are brought to the English classroom by the students through the media and popular culture.

\section{Rebellion and Dissonance}

The last category of affects that this research with English teachers has uncovered involves rebellion and dissonance in the classroom. Critical dissonance is a research methodology for teachers which encourages them to critique and explore the social consequences of their knowledge (Cochran-Smith, 2003). Several English teachers agreed with this way into the 
contemporary English curriculum as it enables inquiry-based learning and teaching for understanding:

Teacher J: The way I work through a book is a semi-reflexive process. I gauge the ways in which the class might react before I bring literature into the room. It's a kind of experimentation. I have to set all of these ideas up before we start reading a text or they won't learn.

This way of using affects taps into pervasive discourses of rebellion and dissonance (Cole, 2005, $2007 \mathrm{~b}, \mathrm{c})$ that may be present in the cohort. Teachers will structure lessons around literature that expresses these ideas, or introduce the topics of rebellion and dissonance through examining current news events. These lessons should not have a negative feel, but use the desires of the participants (affects) to engage with the texts to the advantage of the English teacher. Many of the pre-service students were impressed and surprised at this development in English teaching - as it marks out the ways in which the profession is evolving as the nature of textual authority changes in society. This point also shows how English teachers now need to work with cultural seduction in language and affects to make their classes work (McWilliam, 2000).

\section{Polarisation and Emergence}

The teacher identity Discourses that have been put into play by the ELs and brought to light through this research may be represented in a diagram (Figure 1). Polarisation is shown in this figure by the arrows that jut out horizontally through the teacher identity Discourses. Polarisation is a useful term to use in this context as it describes the ways in which the Discourses may be connected to friction and antipathy between groups involved in curriculum reforms (Lyotard, 1991, p. 76). This figure points to the fact that there is lateral movement between Discourses and that they are not sealed or constituted by privileged spaces. The diagram could be added to indefinitely to show how polarisation may also work along different axes, yet this complexity would make it impossible to understand as a summary of the results of this research project.
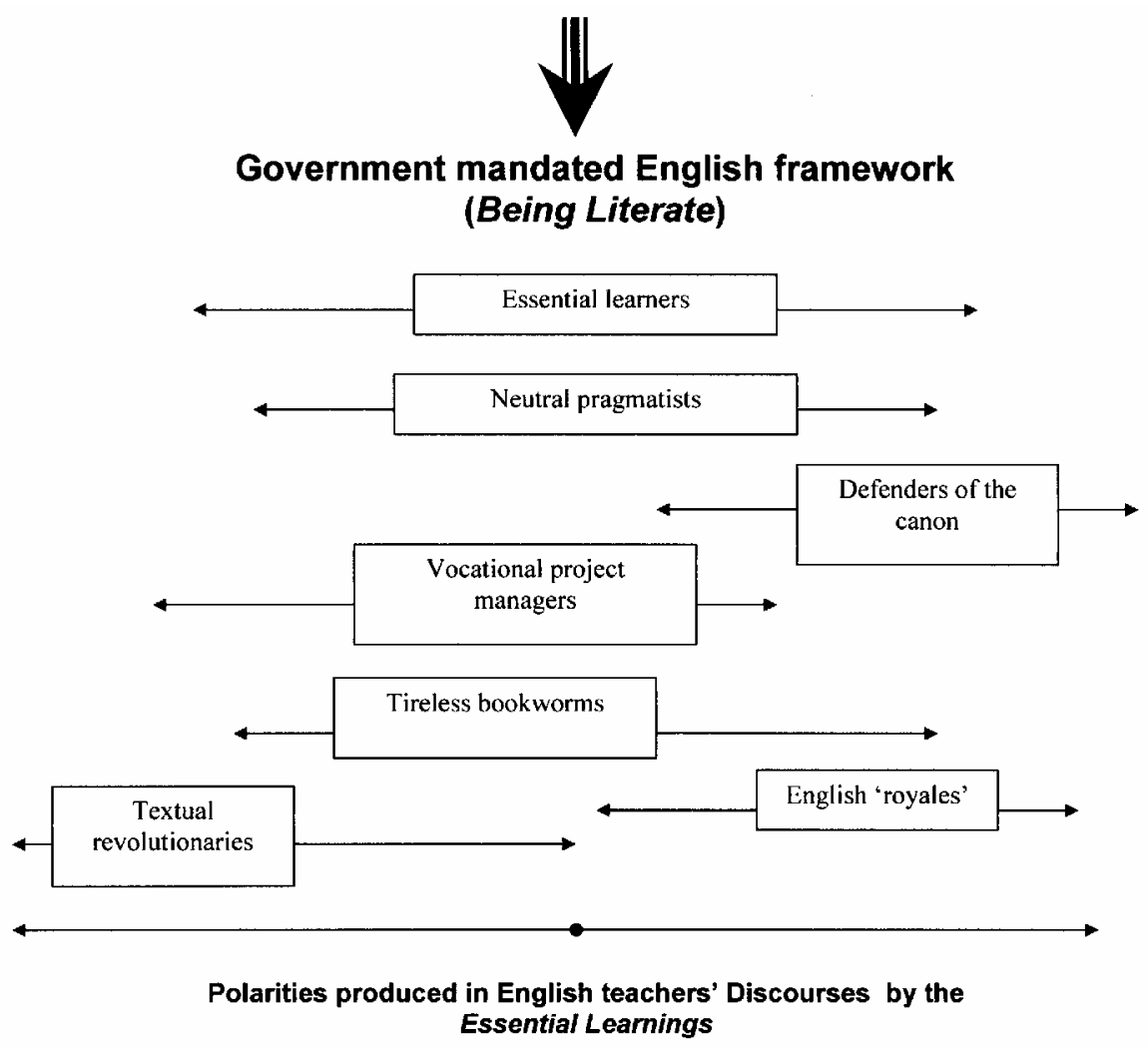

Figure 1. The English teacher identity Discourses and relative positions that have been produced after the introduction of the Essential Learnings. 
Polarisation is the most conspicuous aspect of this mapping as the teachers are forced into positions by the introduction of the new knowledge framework. It could be said that many of them had been happily performing their jobs for many years without having to consider their positioning. In many ways, and as has already been discussed, the introduction of critical literacy as a headline governmental objective may augment polarisation (Hargreaves, 1994). Most governments content themselves with functional and linguistic, rationally defined discrete learning outcomes (Eisner, 1994). These outcomes usually do not produce polarities - in fact they often work to do the opposite and to neutralise debate. I am sure that many English teachers, especially those who endorse critical literacy, have welcomed the Essential Learnings for exactly the reason that serious critical examination of text is now on the agenda. Many teachers may have been working in their English lessons to produce critical thinkers for many years, and perhaps for the first time this is in line with explicit governmental outcomes.

The emotional and affective factors that this research has uncovered may be represented in Figure 2. The through-line of the diagram is a spiral that oscillates between personal English teaching development and the ability to articulate one's philosophy of English teaching (Arnold, 1991). At the top of the spiral is one's power as an English teacher at any given time during a career - below this, the factors of maturation and gender also heavily influence one's emotional state and the consequent textual emotions that one may be able to induce at any given point through the application of affect. Running through these emotional factors in English teaching are the affects of rebellion, dissonance and creativity. Creativity goes through the whole of the figure, and to a certain extent defines the emergent qualities of the teacher (Tochan \& Munby, 1993). These qualities include the ability to work through change, the establishment of shifting yet positive learning relationships and inspirational teaching with elements of spontaneity and surprise. It should also be noted that emergence is non-linear and includes retardation as well as development (Casti, 1989).

Power should not be thought of as the goal of English teaching - though it is always part of any pedagogic and professional roles that one might inhabit. Figure 2 is an attempt to represent the complex nature of emotion in English teaching, and this point has been discussed in detail throughout the course of the project by the main researcher and the pre-service students. This discussion had the aim of looking at the nature of complexity in English teacher identity, and what we may learn from this (Purcell-Gates, 2004). The overall impression was that lessons learnt from life, for example, communicating with one's children or taking on roles of responsibility in the community, will help with understanding how Figure 2 might help to structure English teaching development.

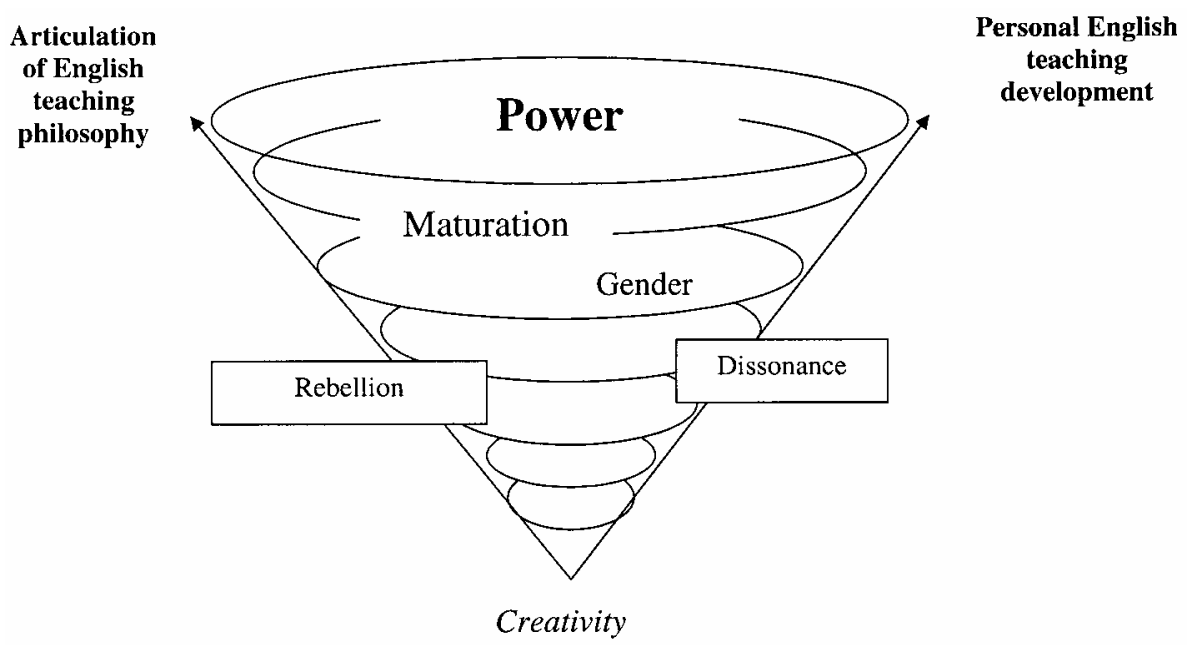

Figure 2. The emotional and affective journey of the English teacher - English teacher identity emergence. 


\section{Conclusion}

This research gives pre-service students an insight into English teaching in Tasmania. On one level, it shows how changes due to curriculum reform can polarise English teachers and make them shift with respect to their job positioning - and on another, it gives them an introduction to the emotional and affective parts of the daily work. As Muchmore (2001, p. 28) has explained when investigating the personal pedagogies of an English teacher, there is a 'complex and multi-layered system of beliefs' to understand. It is only when the teacher is challenged in some way that transformation of these beliefs happens (Tann, 1993), and the relationships between these beliefs come into the light and may be articulated. The ELs works on this level as it has shaken up the idea of English in many teachers' minds, and its introduction in Tasmania has produced the questioning of cultural and social assumptions. These are several excerpts from the pre-service students' selfreflective diaries that relate to these points:

Student A: I was actually teaching today when one of the interviews came back to me. The teacher had been speaking about the ELs and how it was attacking the subject fidelity of English. He wanted more Shakespeare in the curriculum! The kids in the room were bored by the literacy project that had been set, and I was wondering if I could ask the colleague teacher if I could use a different text.

Student B: The project has really helped me to think about my emotions and those in the English teaching classroom. Before I just thought it was a matter of going in there and getting through the text in a professional manner. Now I realise that I bring a whole lot more of ' $m e^{\prime}$ in there.

The knowledge that the students have learnt by taking part in the research is subjective as well as discursive (Masny, 2006). This means that they are assimilating ideas about the construction of English not only as public output, but also as personal experience. On this level, the forces of identity in Figure 2 are activated by polarised beliefs (Leach \& Moon, 1999), as described in Figure 1. This aspect of synthesis and analysis of English is concerned with having the will to carry on, and takes into account the ways in which English may be recast through the unconscious and the imaginary. These long-term goals deal with the possibility that exterior and interior factors in English might not form a dualistic system of division between the inner and the outer in the minds of English teachers. The benefit of this research is to address this possible dualism early on, and to set a course for English teaching careers where the interior and exterior are aligned and reconciled to enhance the power of the future teachers that take part.

\section{References}

Arnold, R. (1991) Writing Development: magic in the brain. Buckingham: Open University Press.

Cardiero-Kaplan, K. (2004) The Literacy Curriculum and Bilingual Education: a critical examination. New York: Peter Lang.

Casti, J.L. (1989) Nonlinear System Theory. New York: Academic Press.

Chevellard, Y. (1991) Le Transposition Didactique: Du savoir savant au savoir enseigné. Paris: La Pensée Sauvage.

Cochran-Smith, M. (2003) Learning and Unlearning: the education of teacher educators, Teaching and Teacher Education, 19, 5-28. http:/ / dx.doi.org/10.1016/S0742-051X(02)00091-4

Cole, D.R. (2005) Education and the Politics of Cyberpunk, Review of Education Pedagogy and Cultural Studies, 27(2), 159-170. http:/ / dx.doi.org/10.1080/10714410590963839

Cole, D.R. (2007a) Teaching Frankenstein and Wide Sargasso Sea Using Affective Literacy, English in Australia, 42(2), 69-75.

Cole, D.R. (2007b) Techno-shamanism and Educational Research, Ashé: Journal of Experimental Spirituality. http: / / ashejournal.com/index.php?id=277

Cole, D.R. (2007c) Virtual Terrorism and the Internet E-Learning Options, E-Learning, 4(2), 116-127. http:/ / dx.doi.org/10.2304/elea.2007.4.2.116

Cope, B. \& Kalantzis, M. (1995) Productive Diversity: organisational life in the age of civic pluralism and total globalisation. Sydney: HarperCollins.

Derewianka, B. (1998) A Grammar Companion for Primary Teachers. Sydney: Primary English Teachers. 
Doecke, B. (2006) Teacher Quality: beyond the rhetoric, in B. Doecke, M. Howie \& W. Sawyer (Eds) Only Connect: English teaching, schooling and community, 195-209. Kent Town, SA: Wakefield Press (AATE).

Doecke, B., Howie, M. \& Sawyer, W. (Eds) (2006) Only Connect: English teaching, schooling and community. Kent Town, SA: Wakefield Press (AATE).

Dowden, T. \& Nolan, P. (2006) Engaging Early Adolescent Students in their Learning Via Student-centred Curriculum Integration. Paper presented at the Australian Association for Research in Education Conference, November 26-30, Adelaide, Australia.

Eisner, E. (1994) Cognition and Curriculum Reconsidered. New York: Teachers College Press.

Fairclough, N. (1992) Discourse and Social Change. London: Polity Press.

Gee, J.P. (2003) Literacy and Social Minds, in G. Bull \& M. Anstey (Eds) The Literacy Lexicon Second Edition, 3-15. Frenchs Forest, NSW: Pearson Education Australia.

Graham, L. (2007) Done in by Discourse ... or the Problem/s with Labelling, in M. Keefe \& S. Carrington (Eds) Schools and Diversity, 2nd edn, 46-65. Frenchs Forest, NSW: Pearson Education Australia.

Gubrium, J.E. \& Holstein, J.A. (Eds) (2002) Handbook of Interview Research: context and method. Thousand Oaks, CA: Sage.

Hargreaves, A. (1994) Changing Teachers, Changing Times: teachers' work and culture in the postmodern age. New York: Teachers College Press.

Holland, N.N. (1968) The Dynamics of Literary Response, 1st edn. New York: Oxford University Press.

Houtz, J.C. \& Kroug, D. (1995) Assessment of Creativity: resolving a mid-life crisis, Educational Psychology Review, 7, 269-300. http:/ / dx.doi.org/10.1007/BF02213374

Keen, S. (2006) A Theory of Narrative Empathy, Narrative, 14(3), 207-240. http: / / dx.doi.org/10.1353/ nar.2006.0015

Kress, G. (2006) Reimagining English: curriculum, identity and productive futures, in B. Doecke, M. Howie \& W. Sawyer (Eds) Only Connect: English teaching, schooling and community, 31-42. Kent Town, SA: Wakefield Press (AATE).

Leach, J. \& Moon, R. (1999) Learners and Pedagogy. London: Paul Chapman.

Lyotard, J-F. (1991) The Inhuman: reflections on time, trans. G. Bennington \& R. Bowlby. Cambridge: Polity Press.

Marshall, B. (2000) The Unofficial Guide: researching the philosophies of English teachers. London: Routledge.

Martin, G., Hunter, L. \& McLaren, P. (2006) Participatory Activist Research (Teams)/ Action Research, in K. Tobin \& J. Kincheloe (Eds) Doing Educational Research: a handbook, 123-148. Rotterdam: Sense Publishers.

Masny, D. (2006) Learning and Creative Processes: a poststructural perspective on language and multiple literacies, International Journal of Learning, 12(5), 147-155.

McWilliam, E. (2000) Stuck in the Missionary Position? Pedagogy and Desire in New Times, in C. O’Farrell, D. Meadmore, E. McWilliams \& C. Symes (Eds) Taught Bodies, 27-39. New York: Peter Lang.

Mellor, B. \& Patterson, A. (2004) Poststructuralism in English Classrooms: critical literacy and after, International Journal of Qualitative Studies in Education, 17(1), 83-98. http: / / dx.doi.org/10.1080/0951839032000150248

Mills, K.A. (2005) Multiliteracies: remnant discourses and pedagogies, in Proceedings of the ALEA/AATE Conference 2005: Pleasure, Passion, Provocation. Gold Coast, Queensland: ALEA/AATE Press.

Mills, K.A. (2006) Critical Framing in Pedagogy of Multiliteracies, in Proceedings of the ALEA/AATE Conference 2006: Voice, Vibes, Visions. Darwin, Australia.

Muchmore, J.A. (2001) The Story of Ana: a life history study of the literacy beliefs and teaching practices of an urban high school English teacher. Paper presented at the Annual Meeting of the American Educational Research Association, Seattle.

Purcell-Gates, V. (2004) Ethnographic Research, in N.K. Duke \& M.H. Mallette (Eds) Literacy Research Methodologies, 92-114. New York: Guilford Press.

Sawyer, W. (2004) Seminal Books on English Teaching, in W. Sawyer \& E. Gold (Eds) Reviewing English in the 21st Century, 23-36. Melbourne: Phoenix Education.

Semetsky, I. (2007) Deleuze, Education and Becoming. Rotterdam: Sense Publishers.

Shulman, L.S. (1986) Those Who Understand: knowledge growth in teaching, Educational Research Review, 57, 4-14. 
Strauss, A. \& Corbin, J. (1998) Basics of Qualitative Research: grounded theory procedures and techniques, 2nd edn. Newbury Park, CA: Sage.

Tann, S. (1993) Eliciting Student Teachers' Personal Theories, in J. Calderhead \& P. Gates (Eds) Conceptualising Reflection in Teacher Development, 53-69. London: Falmer Press.

Tasmania Department of Education (2002) Essential Learnings: learning together. Hobart: Tasmania Education Authority.

Tochan, F. \& Munby, H. (1993) Novice and Expert Teachers' Time Epistemology: a wave function from didactics to pedagogy, Teacher and Teacher Education, 9(2), 205-218. http: / / dx.doi.org/10.1016/0742-051X(93)90055-L

Upton, P. (2005) Re-positioning the Subject: trainee English teachers' constructions of grammar and English. $\mathrm{PhD}$ thesis, University of Nottingham. Retrieved from EDRS.

Varela, F.J., Thompson, E.T. \& Rosch, E. (1993) The Embodied Mind: cognitive science and human experience. Cambridge, MA: MIT Press.

Watt, M.G. (2005) Looking back at Curriculum Change in Tasmania: Is the Essential Learnings Framework Promoting Successful Curriculum Reform? Paper presented at 'Blurring the Boundaries: sharpening the focus', ACSA Biennial Conference, 21-23 September 2005, University of the Sunshine Coast.

http:/ / www.acsainc.com.au/content/watt_-_curriculum_change.doc (accessed 21 August 2008).

DAVID R. COLE is a senior lecturer in English and Pedagogy at the University of Technology, Sydney. His major research areas are multiliteracies, multiple literacies and affective aspects of literacy. He has worked as an international English teacher on four continents, and has published widely in academic journals including English in Australia, Educational Philosophy and Theory and Prospect. He is currently under contract to write three edited academic books on literacy theory, and has published a novel about Colombia called A Mushroom of Glass in 2006. He is presently researching the complex multiple literacies of immigrant families living in New South Wales. Correspondence: Dr David R. Cole, University of Technology, Sydney, Kuring-gai Campus, Lindfield, NSW 2070, Australia (david.cole@uts.edu.au)

[Appendix 1 can be found on the next page] 


\section{Appendix 1}

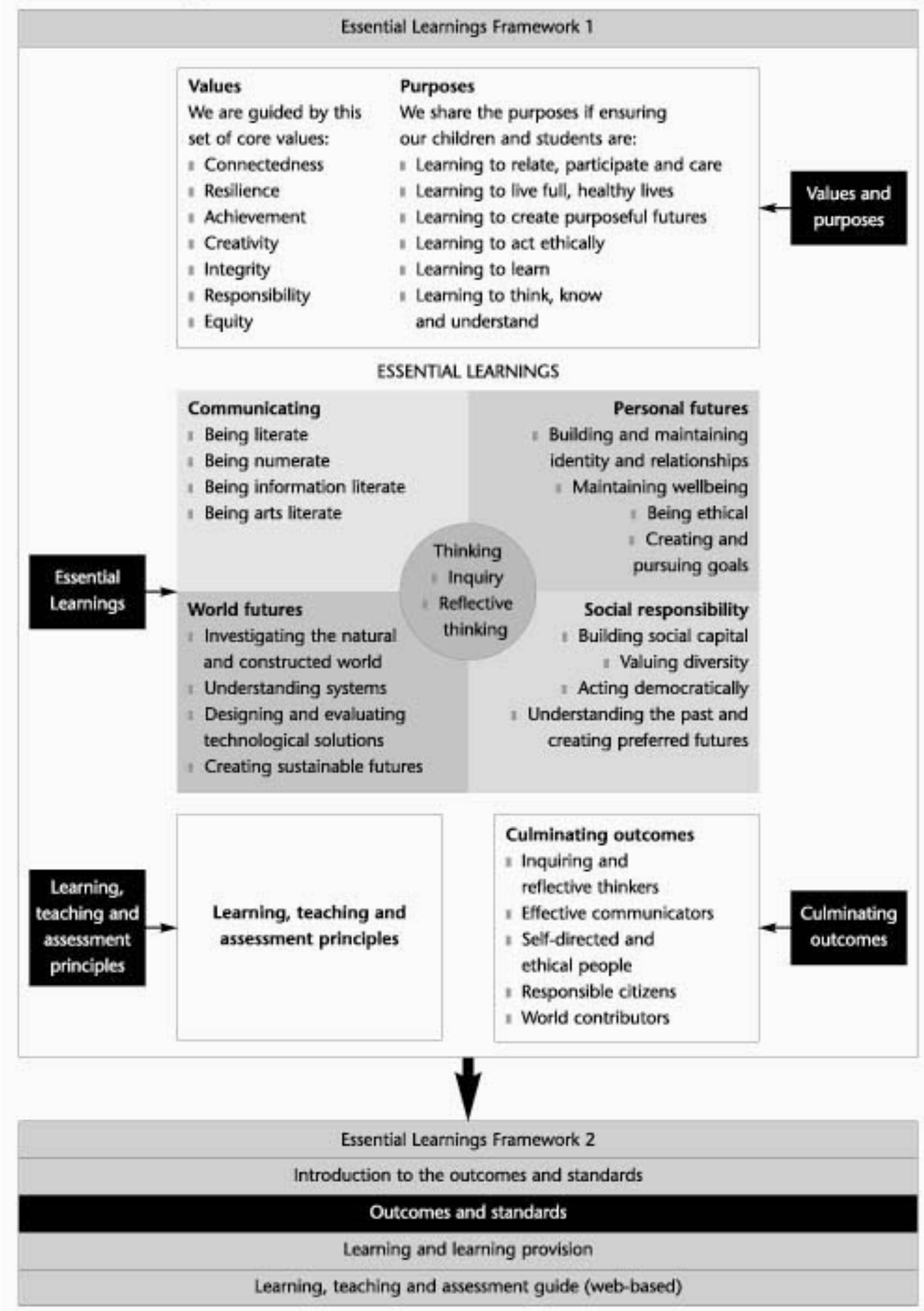

Figure A1. The Essential Learnings Framework 1 (Department of Education, Tasmania, 2002). 